\title{
Göçmen Girişimcilerin Kuruluş Aşaması Finansmanı: İsveç/Göteborg'daki Türk Restoran Sahipleri Örneklemi
}

\author{
Gülşah Kulalı a,b
}

\section{Özet}

Bu çalışmanın amacı, refah devleti İsveç'in Stockholm'den sonra ikinci büyük bölgesi olan Göteborg'daki Türk kökenli göçmen restoran sahibi girişimcilerin kuruluş aşamasında finansal sermaye bulma konusunda ne tür zorluklar yaşadığının ve geliştirdikleri finansman çözümlerinin araştırılmasıdır. İskandinav refah devlet modelinde göçmen girişimcilerin kredi piyasasında ayrımclık yaşayarak finansal sermayeye erişimlerinin sınırlandığı, hatta kimi zaman bu nedenle işyerlerini kapatmak zorunda kaldıkları, hem kamusal hem de akademik platformlarda tartışma konusu olmaktadır. Bu çalışmada kartopu örnekleme tekniği ile yarı yapılandırılmış derinlemesine görüşmeler yapılan dokuz girişimciden sadece biri işyerini kurarken banka kredisi kullanabilmiş, bir diğeri ise kullandığı konut ve araba kredisinin bir bölümünü iş yeri için kullanmıştır. Diğer yedi girişimci banka kredisi başvurusu yapmış fakat ya başvuruları reddedilmiş ya da maliyetlerin yüksekliği nedeniyle kredi kullanamamışlardır. $\mathrm{Bu}$ girişimciler çözüm olarak kuruluş aşaması finansmanlarını aile fonlarını hibe ve borç şeklinde kullanarak sağlamışlardır.
Anahtar Kelimeler

Göçmen Girişimcilik

Kuruluş Aşaması Finansmanı

Türkiye

İsveç

Makale Hakkında

Geliş Tarihi: 14.02 .2020

Kabul Tarihi: 09.09.2020

Doi: 10.18026/cbayarsos.688440

\section{Financing of Immigrant Entrepreneurs in Foundation Phase: Sample of Turkish Restaurant Owners in Sweden/Gothenburg}

\section{Abstract}

The aim of this study is to investigate challenges of immigrant restaurant owner entrepreneurs in Gothenburg (Welfare State Sweden's second largest region after Stockholm) regarding foundation phase financing; and to investigate what their solutions are to those problems. It is often discussed in public and academic platforms that immigrant entrepreneurs experience discrimination in the credit markets, and their access to financial capital is limited, even some has to close their businesses in the Scandinavian welfare state model. Semi-structured in-depth interviews were conducted with nine entrepreneurs, by using snowball sampling technique. Among those nine, only one could use bank credit and another one was able to utilize part of his mortgage and car loans for business purposes. Remaining seven entrepreneurs' credit application were either denied or they could not use the loan because of high costs. As a solution, these entrepreneurs managed to employ their family funds in the form of grants and loans.
Keywords

Immigrant Entrepreneurship

Financing at Foundation

Turkey

Sweden

\section{About Article}

Received: 14.02 .2020

Accepted: 09.09.2020

Doi: $10.18026 /$ cbayarsos. 688440

a İletişim: gulsahy@anadolu.edu.tr

b Dr. Öğr. Üyesi, Anadolu Üniversitesi İ̈BF İşletme Bölümü ORCID: 0000-0001-7843-0965 


\section{Giriş}

Göçmenlerin iş hayatına katılımı konusu Avrupa ülkelerindeki politikacılar ve sosyal bilimciler tarafından entegrasyon tartışmalarında son yıllarda en çok yer verilen konu başlıkları arasındadır. Bu tartışmalardan anlaşılmaktadır ki, Avrupa devletleri kendi içinde ülkeler bazında göçün ve göçmenlerin ekonomik entegrasyonu konularında çok farklı politik anlayışlara sahiptir (Westin vd., 2015, s.12).

Göçmenler tüm ülkelerde işgücü piyasasında birçok zaman sınırlı firsatlar yakalayabilmektedir. Fırsatların sınırlı oluşu beşeri, finansal ve sosyal sermeye kaynaklarının sinırlı oluşundan kaynaklanmaktadır (Bates, 2011; Akresh, 2006; Sundararajan ve Sundararajan, 2015; Alden ve Hammarstedt, 2016). "Neoklasik beşeri sermaye teorisi" ne göre göçmenler, yaşam kalitesini artırmak ve kazançlarını maksimize etmek üzere risk almayı seven, rasyonel bireylerin oluşturduğu bir grup olarak ifade edilmektedir. Bu kişiler başarıya ve beşeri sermayeye yatırım yapmaya yönelik güçlü bir motivasyona sahiptirler. Ayrıca risk taşıyıcılar olarak görülen göçmenler, diğer kişilere göre daha dinamik; kendi işini kurmaya, iş yaratmaya daha çok yatkın ve kendilerine sürekli fırsat yaratan kişiler olarak görülmektedir. Neoklasik beşeri sermaye teorisine göre göçmenlerde işsizlik ve maruz kalınan ayrımcılık, girişimcilik motivasyonunu artıran diğer faktörler olmaktadır (Sanders ve Nee, 1996; Constant ve Zimmermann, 2006).

Göçmen girişimciliğinin her zaman güncel bir konu olmasını iki şekilde açıklayabiliriz: i) II. Dünya savaşından sonraki dönemde OECD ekonomilerinde KOBİlerin rolünün ve ekonomik etkisinin artması (Karmel ve Bryon, 2002), ii) gelişmiş ülkelerdeki göçmenlerin, yerlilere göre küçük işletme kurma eğiliminin daha yüksek olması (Fairlie ve Karashinsky, 2012; Rauhut ve Kompaniets, 2018). Batı toplumlarında göçmenler arasında girişimcilik faaliyetleri 30 yıldan beri artış göstermektedir (Waldinger vd.,1990; Bird ve Wennberg, 2016). Akademik literatürde göçmen girişimcilik konusu en fazla sosyal politika ve girişimcilik alanlarında araştırılmıştır. Bu iki alandaki araştırmaların sonuçlarının buluştuğu temel ortak nokta, Avrupa ekonomilerinde göçmenlerin gerek kamu sektöründe, gerek özel sektörde, gerekse serbest girişimci olarak ülke işgücüne katılımı konusunda zorlukların ve çözüm bekleyen problemlerin var olduğudur. İskandinav ülkeleri özelinde ise göçmen girişimcilikle ilgili yapılan araştırmalar en fazla girişimcilerin ekonomik entegrasyonu ile göçmenlerin ev sahibi ülke toplumuna dahil olması/toplumdan dışlanması konularına yoğunlaşmaktadır (Hjerm, 2004; Hedberg, 2009, Slavnic, 2013).

Bu çalışmanın amacı göçmen girişimciliği literatürüne, refah devleti İsveç'in Stockholm'den sonra ikinci büyük bölgesi olan Göteborg'daki Türk kökenli göçmen restoran sahibi girişimcilerin girişimcilik hikayeleri, ve özellikle kuruluş aşamasında işletmelerinin finansmanı konularında katkı yapmaktır. Ayrıca bu çalışma, Kuzey Avrupa'ya veya İsveç'e göç etmek isteyen ve kendi işini kurmayı düşünen girişimcilere de yol gösterici nitelikte pratik bilgiler sunmaktadır.

İsveç'teki göçmen girişimciler kuruluş aşamasında finansal sermaye bulma konusunda büyük zorluklar yaşamaktadır (Rauhut ve Kompaniets, 2018). İsveç'in İskandinav refah devlet modeli, refah rejiminde devletin taahhüt ve katılımının güçlü şekilde hissedildiği ve Avrupa'nın diğer refah devletlerine kıyasla daha fazla gelir güvencesi ve dengeli gelir 
dağılımı sağladığı bir modeldir. Böylesi bir modelde göçmen girişimcilerin kredi piyasasında ayrımcılık yaşayarak finansal sermayeye erişimlerinin sınırlandığı ve bu nedenle kimi zaman işyerlerini kapatmak zorunda kaldıkları hem kamusal hem de akademik platformlarda da tartışma konusu olmaktadır (Ahmed vd. 2010; Andersson 2011; Alden ve Hammerstedt, 2016).

$\mathrm{Bu}$ çalışma kapsamında görüşülen dokuz girişimciden sadece biri işyerini kurarken banka kredisi kullanabilmiş, biri ise kullandığı konut ve araba kredisinin bir bölümünü iş yeri için kullanmıştır. Diğer yedi girişimci finansmana erişim konusunda banka kredisi başvurusu yapmış fakat ya başvuruları reddedilmiş ya da maliyetlerin yüksekliği nedeniyle krediyi kullanamamışlardır. Bu girişimciler çözüm olarak kuruluştaki finansmanlarını geniş aile fonlarını hibe ve borç şeklinde kullanarak sağlamışlardır.

\section{Göçmen Girişimcilerin Finansman Sorunları}

Göçmenlerin yeni bir ülkede finansal sermayeye erişimi çok yönlü bir problemdir ve bu problemin, ev sahibi ülkedeki sosyo ekonomik koşullar, girişimcilerin bireysel sermayelerindeki ve kültürel geçmişlerindeki farklılıklar ve göçmenlerin ulaşabileceği finansal kurumlar ile ilgili bilgilerin kısıtlı oluşu gibi bir çok kaynağı vardır (Ostrovsky vd., 2019). Kushnirovich ve Heilbrunn (2008) göçmen girişimlerin finansman olanaklarını kısıtlayan faktörlerin, göçmen girişimcinin; ekonomik statüsünün düşük oluşu, etnik bağlarının zayıf oluşu, iş deneyiminin kısıtlı oluşu, ve aynı zamanda göçmen girişimlere devlet desteğinin kullanımının az oluşu olarak sıralamaktadır.

Göçmen girişimciliği literatüründe göçmen girişimcilerin finansman olanaklarını şekillendirmede sosyo kültürel ağların fonksiyonlarına geniş yer verilmektedir. Göçmen girişimcilerin diğer göçmenlerle olan bağlantılarının, finansal sermayeye ulaşmada onlara avantaj sağladığı görülmektedir. (Masurel vd., 2001; Alden ve Hammarstedt, 2016; Eimermann ve Karlsson, 2018). Üst ekonomik sınıftan gelen ve güçlü aile bağları ve etnik ağları sayesinde finansal kaynaklara erişimi daha iyi olan göçmenlerin girişimcilik faaliyetinde bulunma ve başarılı olma olasılıkları yüksek olmaktadır (Zhou, 2004; Anderson ve Miller, 2003). Göçmenlerin etnik grupla bağlantıları ve bu bağlantıların ekonomik fırsat yaratması, Valdez (2003) tarafından arz yönlü olarak izleyen biçimde açıklanmaktadır. Etnik grubun gruptaki göçmenlere sağladığı kaynaklar emlak, para veya bilgi birikimi, kültürel değerler, bilgi zincirleri, yetenekler, liderlik potansiyeli, ve dayanışma gibi kaynaklardır. Bu maddi ve beşeri kaynaklar birleştiğinde ise etnik girişimcilik için fırsatlar ortaya çıkmaktadır.

Bu fırsatları fark etme, girişimcilerin ekonomik değer yaratma potansiyeli olan yeni bir şey yaratma fikrini tanımladıkları ve bu olgunun gerçekleştiği toplumda ihtiyaç duyulduğu da düşünülen, aktif ve bilişsel süreçlerdir (Baron, 2004). Araştırmacılar göçmen girişimcilerin iş fırsatlarını fark etmede ve iş kurmada dört farklı sermayeyi bir araya getirdiğini göstermektedir: sosyal sermaye, kültürel sermaye, ekonomik sermaye ve beşeri sermaye. $\mathrm{Bu}$ sermayelerin ne kadar iyi bütünleştiği göçmen girişimcilerin başarısını belirlemektedir (Sequeira ve Rasheed, 2006; Sundararajan ve Sundararajan, 2015). Bunlardan ekonomik sermaye, Bourdieu (2008) tarafından; girişimcilerin gelirleri, servetleri, finansal mirasları ve parasal varlıklarının toplamı şeklinde tanımlanmıştır. Ekonomik sermaye sıklıkla finansal 
kaynaklara erişim anlamında kullanılmaktadır ve göçmenlerin finansal kaynakları; şahsi birikimleri, ailelerinin birikimleri, sahip oldukları varlıklar, ve kredi olanaklarının bileşiminden olmaktadır. Finansal kaynaklara erişim, göçmenlerin göç ettikleri ülkede yeni bir iş kurup kuramayacağ Wang, 2002). Göçmen girişimcilerin finansman alternatifleri Tablo 1'de yer almaktadır. Kushnirovich ve Heilbrunn (2008) göçmen girişimcilerin finansman kaynaklarını, girişimcinin yakın çevresinden veya resmi finansal kurumlardan elde edilmiş olmak üzere gayri resmi ve resmi olarak iki grupta; etnik toplulukla ilişkili veya ilişkisiz bir şekilde elde edilmiş olmak üzere etnik ve etnik olmayan olarak iki grupta sınıflamıştır. Girişimcinin bu seçimleri birbirini dışlamamaktadır: finansman kaynağı gayri resmi ve etnik olmayan bir kaynak olabileceği gibi; resmi ve etnik bir kaynak da olabilmektedir.

Tablo 1. Göçmen Girişimcilerin Finansman Kaynakları

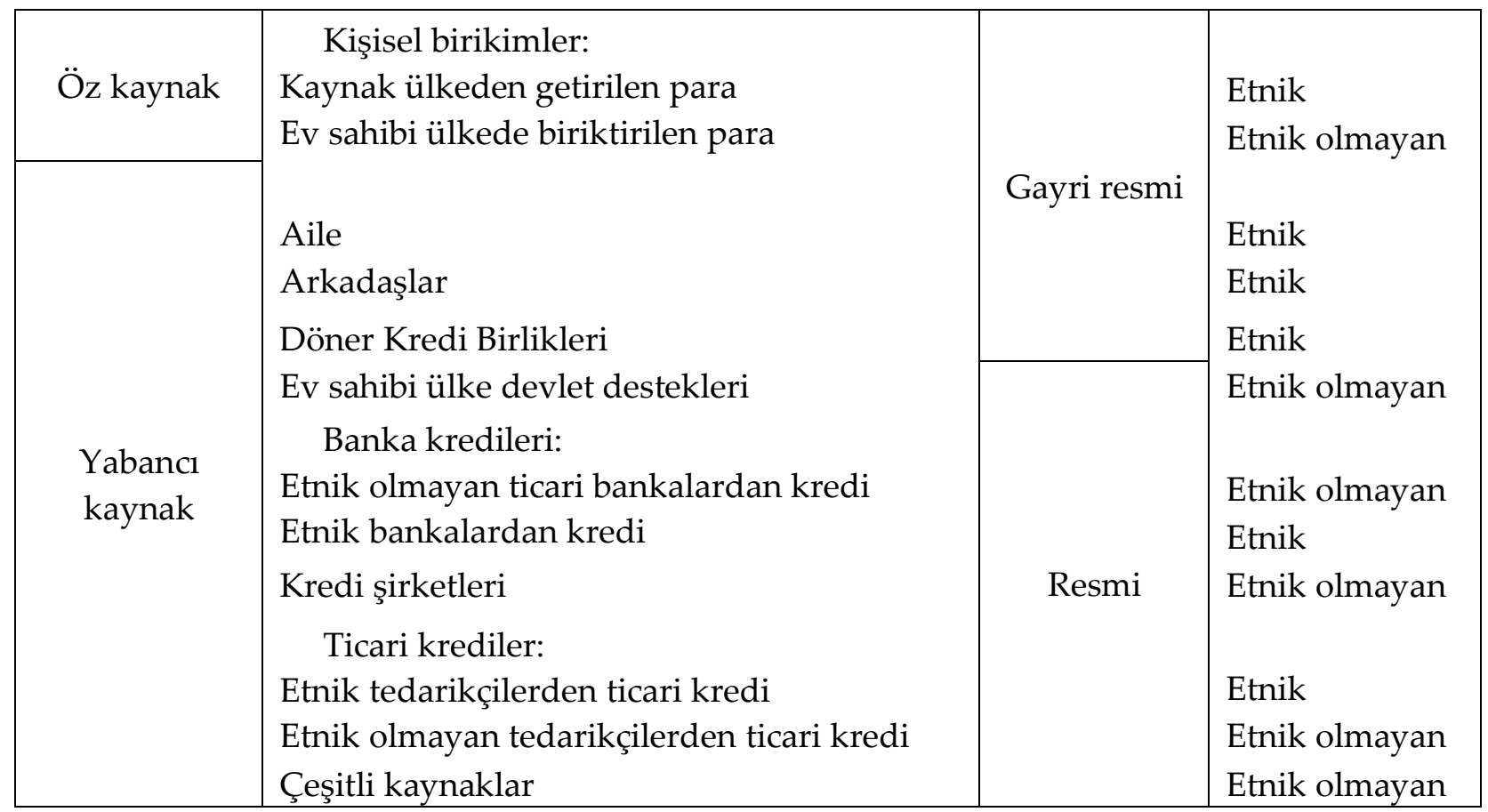

Kaynak: Kushnirovich ve Heilbrunn (2008:169).

Göçmen girişimlerin finansmanı ile ilgili temel sorunlar sermaye yetersizliği ve banka kredilerine erişimin zorluğu ekseninde tartışılmaktadır. Bu finansal kısıtlar yüzünden göçmen girişimciler çokça aile ve arkadaşlar gibi resmi olmayan etnik finansal kaynaklara yönelmektedir. Genel olarak göçmen girişimcilerin bankalardan veya kredi şirketlerinden kredi kullanmalarının pek muhtemel olmaması sıklıkla dil bilmemenin göçmenlerin resmi finansal kurumlara erişimini kısıtlaması, resmi kredi geçmişlerinin ve bir kredi notlarının olmayışı, ticari kredi kullanamamaları, ve mali idareler ve bürokratik mevzuatla ilgili problemler ile bankaların göçmen girişimcilerin kredi başvurularını değerlendirmek için ek kaynak ve fazladan zaman ayırma yanlısı olmamaları olarak gösterilmektedir (Tseng, 1997; Aaronson vd., 2000; Collins, 2003; Constant, 2005; Ostrovsky vd., 2019). Göçmen girişimcilerin banka kredilerine ve ticari kredilere erişimlerinde bu türlü kısıtlar olduğu için, işletmelerini ailelerinden ve arkadaşlarından aldıkları borçlar ile finanse etmeleri daha muhtemel olmaktadır. 


\section{İsveç'teki Göçmenlerin İş Hayatına Katılımı}

2019 Kasım ayı itibarıyla İsveç nüfusu 10.323.857 olmuştur (Statistics Sweden, SCB, erişim tarihi 04.02.2020). İsveç nüfusu içinde yabancı vatandaşlar (teki İsveç vatandaşlığı olmak üzere çifte vatandaşlar hariç) \%8.9 oranındadır. "Yabancılık geçmişi olanlar", yani yabancı bir ülkede doğmuş olan (\%18.5) ve İsveç'te doğmuş fakat anne-babası yabancı bir ülkede doğmuş olan kişiler (\%5.6) ise toplam nüfusun \%24.1 ini oluşturmaktadır (Statistics Sweden, SCB, erişim tarihi 07.08.2018).

Türkler 2007 yılı itibarıla İsveç'teki onuncu en büyük göçmen grup olmuştur. İsveç'te Türk göçmen sayısı 38.158 olup, bu kişilerin \%51 i Stokholm'de yaşamaktadır. Kalan \%49 büyük ölçüde Göteborg ve Malmö de de yaşamaktadır (Statistics Sweden, SCB). Tablo 2'de İsveç'teki Türkiye doğumlu göçmenlerin oturma izni alma nedenleri ve sayısı yer almaktadır.

Tablo 2. İsveç'te Türkiye Doğumlu Göçmenlerin Oturma İzni Alma Nedenleri ve Sayısı, 1987- 2014

\begin{tabular}{lrrr}
\hline Oturma izni alma nedeni & Kadın & Erkek & Toplam \\
\hline Aile birleşmesi & 11500 & 12300 & 23800 \\
İltica & 2100 & 2800 & 4900 \\
Çalışma & 400 & 2600 & 3000 \\
Öğrenim & 400 & 800 & 1200 \\
Diğgr & 100 & 100 & 200 \\
Bilinmiyor & 2300 & 3400 & 5700 \\
Toplam & 16900 & 22000 & 39900 \\
\hline
\end{tabular}

Kaynak: Statistics Sweden, SCB, https://www.scb.se/om-scb/samordning-av-sverigesofficiella-statistik/

İsveç'te finans-dışı sektörde faaliyet gösteren mikro işletmelerin istihdam payı 2005 yılı için Avrupa ortalaması olan \%30'un altında, yaklaşık \%25 olmuştur. Benzer oran küçük ölçekli işletmeler için Avrupa ortalamasına çok yakın ve yaklaşık \%20 olmuştur (Bhaird, 2010). İsveç' teki bu mikro ve küçük işletmelerin içinde çok sayıda göçmen girişimci bulunmaktadır. İsveç'teki göçmen girişimcilerin işletmelerinin performansları, İsveçli girişimcilerin işletmelerinin performanslarına nazaran, sınırlı fırsatlar nedeniyle sınırlı kalabilmektedir. Aynı zamanda İsveç'teki göçmen girişimciler, maaşlı bir işte çalışan göçmenlere göre daha az gelir elde etmektedir. (Hjerm, 2004; Efendic vd., 2016; Rauhut ve Kompaniets, 2018).

2019 Aralık itibarıyla İsveç'te 15-74 yaş arası işsizlik oranı \%6.9 olmuştur (Statistics Sweden, SCB, erişim tarihi 04.02.2020). 1993-1996 ve 2006-2007 yıllarında İsveç'te 25-64 yaş arası 
işsizlik oranlarının daha önceki dönemlere göre yüksek olduğu görülmektedir. Bu dönemler ekonomik kriz dönemleri olarak değerlendirilmektedir. Schröder (2015, s.13) krizlerin göçmenler üzerinde İsveç kökenlilere göre daha ciddi etkileri olduğunu ve göçmenlerin İsveçlilere göre iş döngüsüne karşı daha savunmasız olduğunu belirtmektedir. Dahası, bu savunmasızlık Avrupa dışındaki ülkelerden göç edenler arasında daha keskin bir şekilde ortaya çıkmaktadır.

Schröder'in bu bulgusu ile birlikte, Avrupa'da, aynı ülkede ve yabancı ülkede doğanlar arasındaki istihdam açığı bilgisi, dikkat çekicidir. İsveç, Avrupa'da Hollanda'dan sonra söz konusu açığın en fazla olduğu ikinci ülkedir. İsveç'te İsveç doğumlular arasında istihdam oranı \%84,8 iken yabancı ülke doğumlular arasında istihdam oranı \%68,4'tür. İstihdam açığı, aradaki fark olan \%16,4 kadardır (Eklund ve Braunerhjelm, 2018: 193).

Bu gerçek göstermektedir ki, İsveç, yabancı ülke doğumluların iş bulma konusunda birçok Avrupa ülkesine nazaran daha çok zorlandığı bir ülkedir. Nitekim bu çalışmada Göteborg'daki Türk restoran sahipleri ile yapılan yarı yapılandırılmış derinlemesine görüşmelerde girişimcilerin neredeyse tamamı, İsveç'e göç ettiklerinde eğitimlerine uygun başka işler bulamadıkları için restoran açmaya yöneldiklerini belirtmiştir. Dalhammar (2004) da Stockholm/Kista'daki göçmen girişimcilerle ilgili çalışmasında, göçmen girişimcilerin, girişimci olmadan önce, kendi eğitimlerine uygun işler bulmada büyük zorluklar yaşadıklarını açıklamaktadır. Bulgularına göre bu girişimciler iş bulamadıkları için kendi işlerini kurmak zorunda kalmakta ve çoğu zaman kendi eğitimlerini kullanamamaktadır.

Göçmenlerin iş hayatına katılımı ile doğrudan ilgili olan bir unsur, kamu harcamaları içinde sosyal korumaya ayrılan paydır. İsveç, 2016 yılında GSYH'sinin \%50,2 si kadar kamu harcaması yapmıştır. Bu oran Avrupa ülkelerinde aşağı yukarı benzer durumdadır. İsveç ekonomisinde kamu harcamaları içinde, GSYH'nin \%20,9 ile en çok pay sosyal korumaya ayrılmıştır. (Bu iki oran sırasıyla OECD ortalaması için \%43,8 ve \%16,5; Amerika Birleşik Devletleri için \%37,7 ve \%7,8 şeklindedir) (OECD 2017). Eklund ve Braunerhjelm (2018: 179), İsveç'te göçmenlerin ekonomik olarak entegrasyonunun ne kadar etkili olduğunu göstermek için, sosyal katkı alan göçmenlerin oranını ve bu kişilerin göç etmelerinin üzerinden kaç yıl geçtiği bilgisini kullanmıştır. Buna göre sosyal katkı alan göçmenlerin oranı göçün ilk yılı yaklaşık \%55 olurken, bu oran ilk beş yılda yaklaşık \%30'a, ilk on yılda yaklaşı \%20'ye, ilk 15 yılda yaklaşık \%10'a, ve ilk 20 yılda \%10'un altına düşmektedir. Bu oranın göç yılını izleyen yıllarda giderek azalması, ekonomik entegrasyonun önemli ölçüde sağlandığının bir göstergesi olarak yorumlanmaktadır. Çünkü, yıllar içinde sosyal katkı alımının azalması, sosyal katkı alan kişilerin zamanla bir işte çalışır hale geldiğini ve bu nedenle katkı almayı bıraktıklarını göstermektedir.

\section{OECD, Avrupa ve İsveç’te Göçmen Girişimciliği}


Girişimcilik faaliyetleri, göçmenlerin ekonomik hareketliliği için fırsatlar yaratmaktadır (Sanders ve Nee, 1996; Rajman ve Tienda, 1999). Göçmenler kendi iş yerini açmayı, işgücü piyasasında maaşlı bir iş bulma fırsatları önünde engeller olduğunda ekonomik hareketlilik için alternatif bir strateji olarak kullanmaktadır. Özellikle ev sahibi ülkede genel işsizlik oranı arttıkça, göçmenler işgücü piyasasından daha çok dışlanmakta ve girişimci olmaya bir nevi zorlanmaktadır (Van Tubergen, 2005). İsveç'teki göçmenlerle ilgili yapılan çalışmalarda (Levent ve Nijkamp, 2009; Carlsson ve Rooth, 2007) ortaya çımıştır ki göçmenler ve çocukları, özellikle kendileri ve/veya aileleri OECD dışı ülkelerde doğanlar, sıklıkla sosyoekonomik entegrasyonla ilgili ayrımcılık, kalifiye yetersizlikler ve göç edilen ülke ile İsveç arasındaki kültürel farklılıklar kaynaklı zorluklarla karşılaşmaktadır.

Göçmen girişimciliğin devletler tarafından desteklenmesi konusunda ülkeler arasında farklılıklar bulunmaktadır. Bu konuda temel varsayım, etnik girişimcilerin, girişimci sayısını ve girişimcilik kalitesini artırmak adına getirilecek kanunlardan her zaman fayda göreceğidir. Bu kanunlar ekonominin yeniden düzenlenmesi, daha şeffaf ve hizmet odaklı bürokrasinin sağlanması, vergi rejimleri yapılması, mikro-kredi sistemlerinin desteklenmesi, girişimcilik eğitiminin müfredatın bir parçası haline getirilmesi ve destekleyici kanunların çıkarılması şeklinde ortaya çıkmaktadır. Bu konuda ülkeler arasındaki farklılıkların bir nedeni ülkelerin farklı göç tarihleri olabilir. Örneğin Çoğu Kuzeybatı Avrupa Ülkesi İkinci Dünya Savaşı sonrası yoğun kitlesel göç almıştır ve bu ülkeler diğer Avrupa Ülkelerine göre yasal refah düzenlemelerini daha erken geliştirmişlerdir (Rath, 2010). Dolayısıyla diğer ülkelere kıyasla göçmen girişimciliği destekleyecek yasalar bu ülkelerde daha fazla ve daha kapsamlı olması normaldir denilebilir.

Araştırmalar, hemen her ülkede kendi işini kurma yeteneği konusunda yerliler ve göçmenler arasında farkların olduğunu göstermektedir. Göç olayının kendisi gibi, girişimcilik de risk alma ile ilgilidir ve göçmenlerin genellikle iş kurmak için uygun risk tutumuna sahip olduğu, yani risk iştahının yüksek olduğu kabul edilir. Etnik azınlıkların yerlilere göre girişimci olma eğiliminin daha fazla olması, zorlukların ve olumsuz olayların yeni firma oluşumlarını tetiklediğini öne süren "marjinasyon teorisi" ile ilişkilendirilebilir. Bu teoriye göre, yeni bir teşebbüs kurulması her zaman bilinçli ve maksatlı bir hareket veya rasyonel bir karar olmayabilir. Göçmen olsun olmasın, birçok insan için yeni bir iş kurmak, daha önceki hayatının parçalanması ile başlamaktadır. Hele ki etnik veya göçmen azınlık grupları gibi sosyal sisteme tam olarak adapte olamayabilen kişilerin sosyal pozisyonları, bazen onları kendi işlerini kurmaya zorlayabilir. Bu kişiler için kendi işinde çalışmak sadece para kazanmak için bir araç olmakla kalmayıp, aynı zamanda tanınma ve sosyal kabul görme yolu da olmaktadır (Levent, 2002).

Göçmen girişimcilerle ilgili kapsamlı bir raporda (International Migration Outlook, OECD, 2009) OECD ülkelerinde ortalama olarak göçmenlerin yerli girişimcilerden biraz daha fazla girişimci özelliği gösterdiğini ortaya konulmuştur. Raporda ülkeler arasında önemli farklılıklar bulunduğu; bu farklılığın sebebi olarak da işletme çevresi, göçmenlerin karşı karşıya kalabileceği çeşitli sınırlamalar, göçmenlerin ve yerlilerin sosyo demografik farklılıkları, göç eğilimlerinin özellikleri ve göçmen çalışanların sektörel dağılımı gibi faktörlerin olabileceği belirtilmektedir. Göçmenler arasında yüksek sayılabilecek girişimcilik oranlarını Andersson vd. (2013) göçmenlerin etnik yerleşim yerlerinde yaşaması ve bu 
şekilde etnik ağlardan faydalanması ile ilişkilendirmektedir. Aynı raporda, girişimcilik faaliyetinde bulunma olasılığının önemli belirleyicilerinden biri, kişinin bireysel geçmişinin ve deneyimlerinin olduğu belirtilmektedir. Genel olarak girişimciler erkek, orta yaşlı ve kalifiye kişilerden oluşmaktadır. OECD ülkelerindeki göçmen girişimcilerin dörtte biri 35 yaşın üzerinde olup, yabancı doğumlu girişimciler yerli doğumlu girişimcilerden daha gençtir. Göçmen girişimcilerin üçte ikisi 10 yıldan daha uzun zamandır ev sahibi ülkede kalmaktadır. Göçmen ve maaşlı olarak başka bir işte çalışanların yaklaşık \%50'si bu durumdadır. Göçmenler yerlilere göre daha düşük sosyal sermaye, daha kısıtlı finansman aracı ve fon bulmada daha fazla zorluk ile karşı karşıyadır. Bu kısıtlamaların ev sahibi ülkede yaşama süresi arttıkça azaldığı görülmektedir (International Migration Outlook, OECD, 2009). OECD ülkelerinde Avrupa kökenli fakat Avrupa Birliği üyesi olmayan ülkelerden gelen göçmenlerin ise İngiltere $(\% 24,2)$, Belçika $(\% 16,1)$ ve Fransa $(\% 15,1)$ ülkelerinde, diğer ülkelere nazaran daha yüksek oranda girişimci oldukları görülmektedir (Fairlie ve Lofstrom, 2015; Lofstrom ve Wang, 2006).

Avrupa'da girişimcilerin büyük bölümü perakende ticaret, inşaat, konaklama ve g1da hizmetleri ile profesyonel ve bilimsel sektörlerde iken küçük bir bölümü imalat ve destek hizmetlerindedir. (Aydın vd. (2011), OECD, 2010, s.27-37 içinden alıntılamıştır). İsveç'te neredeyse her şehirde, farklı iş kollarında, göçmenlerin sahibi olduğu küçük ve mikro işletmeler vardır. İsveç'teki göçmen girişimciler en fazla hizmet sektöründe, özellikle yemek servisi ve restorancılık alanlarında iş kurmaktadır (Rauhut ve Kompaniets, 2018). NUTEK verilerine göre de İsveç'te girişimciler tarafından kurulmuş işletmeler en çok ticaret, otelcilikrestorancılık ve kişisel bakım hizmetleri sektörlerindedir (Evansluong, 2016). Bu işletmelerin kurulması, girişimcilerin resmi kaynaklardan daha çok gayri resmi kaynaklardan elde ettikleri bilgi, tavsiye ve sermayeye bağlı olmaktadır. Göçmen girişimcilerin "çok davetkar olmayan" (Yazdanfar vd. 2015) bir sosyal çevre ile karşılaşması, onların kendi etnik ağına daha çok güvenmesine neden olmaktadır. Bu gibi nedenlerle İsveç'teki göçmenlerin aile kaynakları, göçmenlerin ülkeye ekonomik entegrasyonu için önemli bir faktör olarak karşımıza çıkmaktadır. Bird ve Wennberg (2016) araştırmalarında, İsveç'te 1825 adet göçmen girişimcinin girişimcilik faaliyetlerine devam etme eğiliminde bu kişilerin coğrafi olarak yakın yerlerde aile üyelerinin yaşamasının etkili olduğunu bulmuşlardır. Geniş aile göçmen girişimciye bedava işgücü, tavsiye, ağlar, bilgi birikimi ve moral destek gibi gayri nakdi kaynakların yanında, finansal sermaye gibi nakdi kaynakları da sağlamaktadır. Geniş ailenin finansal sermayesi hem maaşlı işlerini bırakmalarında, hem de girişimcilik faaliyetinde bulunmalarında etkili olmaktadır. Yazarlar göçmenlerin maaşlı işlerini bırakmalarında, yerli eşlerinden kaynaklı akrabalık ilişkilerinin de etkili olduğunu bulmuştur.

İsveç'te göçmen girişimcilerin, maaşlı bir işte çalışan göçmenlerden daha az para kazandığ gerçeği, zaman zaman politikacılar arasında tartışma konusu olmaktadır (Bel Habib, 2001; Hjerm, 2004). Bu durumda istihdam edilmenin yanı sıra, işin ne kadar kalifiye bir iş olduğunun önemi de ortaya çıkmaktadır. Feldman (2006) Stockholm'de bilgi ve iletişim teknolojileri sektöründeki üç farklı göçmen girişimcinin işletmelerinde maaşlı çalışan göçmenlerle yaptığı yarı yapılandırılmış derinlemesine görüşmelere dayandırdığı çalışmasında, işin gerektirdiği teknik yeterlilikler arttıkça, göçmen çalışanların "dişarıdan gelen" değil, "içeriden" biri olma durumunun ortaya çıktığını belirtmektedir. Teknik yeterlilikleri yüksek olup maaşlı bir işte çalışan göçmenlerin, girişimci göçmenlerin 
yabancılık yükümlülügünden kaynaklanan ve maruz kaldıkları fon yaratma zorlukları, pazarı ve sistemi iyi tanımama ve karmaşık bürokrasi gibi zorluklara (Irastorza ve Pena, 2014), teknik yeterlilikleri sayesinde, girişimci göçmenlerden daha az etkilendikleri düşünülebilir.

Göçmen girişimcilerin İsveç'teki küçük ölçekli işletmelerinin performansını araştıran Efendic vd. (2016) OECD ülkelerinden gelen ikinci nesil göçmenler tarafından yönetilen işletmelerin, İsveçli girişimciler tarafından yönetilenlere göre daha yüksek büyüme oranları olduğunu; fakat OECD dışı ülkelerden gelen göçmenlerin yönettikleri işletmeler için tam tersi durum olduğunu bulmuştur. Göçmen grupları arasındaki bu farklılık, İsveç'te göçmen girişimler arasında ekonomik entegrasyon konusunda, göçmenlerin kaynak ülkelerine göre bir tabakalanma olduğuna işaret etmektedir (Blackburn ve Ram, 2006).

Göçmenlerin bazıları çoğu Avrupa ülkesinde olduğu gibi İsveç'te de etnik yerleşim yerlerinde ikamet etmekte ve etnik ağındaki kişilerle görüşmektedir (Eimermann ve Karlsson, 2018). Andersson vd. (2013) İsveç'teki Türkiye'nin de dahil olduğu Ortadoğu kökenli göçmen girişimcilerle ilgili çalışmasında, etnik yerleşim yerlerinin ve etnik ağların göçmenlerin kendi işlerini kurmasında hem avantajlı hem de zorluk yaratan faktörler yarattığı ortaya çıkmıştır. Avantaj, İsveçlilerin alıp-satamadığı etnik pazara yönelik ürün ve hizmetlerin bu mahallelerde göçmenlerin kendi iş yerlerinde alıp-satması nedeniyle girişimcilik faaliyetleri yapma eğiliminin artması şeklinde ortaya çıkmaktadır. Zorluk ise etnik ağ büyüdükçe kendi işini kuran göçmen girişimciler arasında rekabetin artmasıyla oluşmaktadır.

2007 yılında yapılan bir ankete göre Stokholm'de yaşayan ve ebeveynleri Türkiye'de doğmuş olan 18-36 yaş arası 124 erkeğin \% 11.5 i; 126 kadının \%2.3 ü girişimcilik faaliyetinde bulunarak kendi iş yerini açmıştır. Aynı yaş aralığında ve aynı büyüklükteki örneklemde İsveçli referans grupta erkeklerin \%7.8 i; kadınların \%4.7 si kendi işinde çalışmaktadır. (Schröder, 2015, s.103). Bu bilgiler, girişimcilik faaliyetlerinin, Türkiye'den İsveç'e göç eden kişiler için ekonomik entegrasyonun önemli bir unsuru olduğunu göstermektedir.

\section{Göteborg'daki Göçmen Türk Girişimcilerin Kuruluş Aşaması Finansmanı}

Göteborg bölgesinde 2018 yılı sonu bilgilerine göre nüfus 1.028.248 olmuştur ve bu nüfus içinde yabanciların oranı \%11.6, yabancı ülke doğumluların oranı \%26.9 dur (https://www.citypopulation.de/en/sweden/metrogoteborg/, erişim tarihi 04.02.2020). 2016 yılında Göteborg'a yeni gelenlerin sayısı 3.300 olmuştur. Bu sayı, tüm ülkeye gelenlerin \%4.7 sini oluşturmaktadır. Bu oran ülke ortalamasının altındadır. Oranın düşük olmasında, konut arzındaki azlık ve konut açığı ile ilgili sorunun önemli rolü vardır. Göteborg' yeni gelenlerin iş bulmaları ile sorunlarından en önemlisi, ülke için yüksek sayılabilecek büyüme oranlarına (yaklaşık \%3.5) karşılık, küresel ekonomik belirsizlikler ve yerel kapasite açıkları, özellikle işgücü açığı nedeniyle işlerle yeterliliklerin eşleşememesi sorunu olarak görülmektedir (City of Gothenburg Annual Report 2016, p.13). Sassen'in çalışmalarında (1998, 2001 ve 2002) belirttiği gibi, şehirler arası farklı kültürel gruplara ait ağlar ve örgütler sinerji yaratarak, şehirlerin birbiri ile olan rekabet yeteneğini de güçlendirmektedir. Bu anlamda şehirlerde 
göçmen girişimciliğin gelişimi hem kültürel çeşitliliğin bir meyvesi olarak, hem de kültürel çeşitliliğin gelişmesi için bir katalizör olarak değerlendirilebilir.

İsveç'te istihdam konusunda göçmenlerle ilgili çok dikkat çekici bir nokta, 2016 yılı verilerine göre İsveç doğumlular arasında işsizlik oranı \%4 iken, Avrupa ülkeleri dışındaki ülke doğumlular arasında işsizlik oranının \%31 olmasıdır. \%31 in içinde tüm eğitim seviyelerine sahip kişiler yer almaktadır. Bu iki oran arasındaki makasın gelecek yıllarda daha da artacağı tahmin edilmektedir (City of Gothenburg Annual Report 2016, p.13). Stockholm ve Malmö ile karşılaştırıldığında Göteborg'da işsizlik oranı Stockholm'den daha yüksek, Malmö'den daha düşüktür. Tablo 3'te üç bölge ve İsveç geneli için işsizlik oranları yer almaktadır. “Göçmenlerin işgücü piyasasına entegrasyonu, Göteborg'un işgücü açığı, ayrımcılık ve kutuplaşma ile mücadelesinde anahtar niteliğindedir" (City of Gothenburg Annual Report 2016, s.13).

Tablo 3. Kayıtlı İşsizlik oranı, İşgücünün yüzdesi olarak

\begin{tabular}{lrrr}
\hline 16-64 yaş & $\mathbf{2 0 1 4}$ & $\mathbf{2 0 1 5}$ & $\mathbf{2 0 1 6}$ \\
\hline Stockholm & 6.6 & 6.4 & 6.1 \\
Göteborg & 8.8 & 8.4 & 7.8 \\
Malmö & 14.9 & 15 & 14.9 \\
İsveç & 8 & 7.8 & 7.6 \\
18-24 yaş & $\mathbf{2 0 1 4}$ & $\mathbf{2 0 1 5}$ & $\mathbf{2 0 1 6}$ \\
\hline Stockholm & 8.6 & 7.5 & 6.6 \\
Göteborg & 13.1 & 10.9 & 9.1 \\
Malmö & 23.3 & 21.6 & 20.3 \\
İsveç & 15 & 13.3 & 11.7 \\
\hline
\end{tabular}

Kaynak: City of Gothenburg Annual Report 2016 içinde, Swedish Public Employment Service.

Göteborg bölgesinde Türk kökenli girişimciler gıda sektöründe yoğunlaşmaktadır. Bu kişiler büyük bir çoğunlukla İtalyan restoranı açma şeklinde girişim yapmışlardır. Yazar tarafından Göteborg Belediyesi yetkilileri ile yüz yüze ve telefonda yapılan görüşmelerde bölgede 25 ila 30 adet Türk kökenli İtalyan restoranı sahibi olduğu öğrenilmiştir. Sayıdaki belirsizliğin nedeni, yetkililer tarafından, bazı girişimcilerin restoranlarını (İsveç'li) eşlerinin adına açması olarak açıklanmıştır. Bu girişimcilerden, konu ile ilgili geniş bilgi alınabileceği tespit edilen 
biri ile (1 numaralı girişimci) irtibat kurulmuş ve diğer girişimcilere onun verdiği bilgileri takip ederek ulaşılmış ve kartopu örneklemesi yapılmış olunmuştur. Kartopu (zincir) örnekleme tekniği, evreni oluşturan birimlere erişmenin zor olduğu veya evren hakkındaki bilgilerin (büyüklük ve bilgi derinliği vb.) eksik olduğu durumlarda kullanılmaktadır (Patton, 2005; Creswell, 2013). Bu teknik kullanılarak bu bölgede İtalyan restoranı sahibi olan dokuz adet Türk girişimciye ulaşılmıştır. İlk görüşülen girişimci, akrabası olan iki girişimciye yönlendirmiş, onlar ve daha sonra görüşülen diğerleri de diğer girişimcilere yönlendirmiştir. Dokuz girişimci artık yeni bir girişimciye yönlendirmemiş ve zincirde aynı isimler tekrarlanmaya başlamıştır. Kartopu örnekleme tekniğinde zincir içinde birkaç isim tekrar tekrar bahsedildikçe zincir birleşir ve örneklem tamamlanır (Kothari, 2004). Göteborg Belediyesinden alınan bilgiler çerçevesinde bu dokuz girişimci dışındaki girişimcilere de ulaşılmaya çalışılmış fakat bu girişimler olumsuz sonuçlanmıştır.

Bu bölüm, Göteborg bölgesinde restoran sahibi dokuz adet Türk göçmen girişimci ile yüz yüze yapılan yarı yapılandırılmış derinlemesine görüşmelere dayanmaktadır. Dokuz işletmenin her birinin sahibi bir göçmen girişimcidir. Görüşmelerin tamamı 2018 TemmuzAğustos arasında bizzat yazar tarafından girişimcilerin restoranlarında ve servis saatleri dışında gerçekleştirilmiştir. Görüşme sorularının hemen hepsi açık uçlu "neden?" ve "nasıll?" sorularıdır. Tablo 4'te dokuz adet girişimciye ilişkin demografik bilgiler yer almaktadır. Girişimcilerin ve restoranların ad ve adresleri bu metinde yer almamaktadır, fakat istenildiği takdirde bu konuda yazarla iletişime geçilebilir. Tablo 5 'te ise girişimler ile ilgili temel bilgiler yer almaktadır. Avrupa Birliği sınıflandırmasına göre (Avrupa Komisyonu, 2003) çalışan sayısı ve yıllık ciro dikkate alındığında dokuz işletmenin tamamının mikro ölçekli olduğu görülebilir.

Tablo 4. Girişimcilerin Demografik Bilgileri

\begin{tabular}{llllll}
\hline & $\begin{array}{l}\text { Doğum } \\
\text { Yılı }\end{array}$ & Doğum Yeri & Cinsiyet & Eğitim & $\begin{array}{l}\text { İsveç'e İlk Göç } \\
\text { Yılı }\end{array}$ \\
\hline Girişimci 1 & 1965 & Konya & Erkek & Ortaokul & 1995 \\
Girişimci 2 & 1949 & İran & Erkek & Üniversite & 1990 \\
Girişimci 3 & 1957 & Giresun & Erkek & Lise & 1974 \\
Girişimci 4 & 1969 & Tokat & Erkek & Lise & 1991 \\
Girişimci 5 & 1970 & Adiyaman & Erkek & İlkokul & 1999 \\
Girişimci 6 & 1980 & Kuzey Irak & Erkek & Lise & 2001 \\
Girişimci 7 & 1978 & Mardin & Erkek & Lise & 1981 \\
Girişimci 8 & 1962 & Malatya & Erkek & Lise & 1991 \\
Girişimci 9 & 1977 & Konya & Erkek & Lise & 1999 \\
\hline
\end{tabular}


Girişimcilerin hepsi Anadolu'nun çeşitli şehirlerinden İsveç'e göç eden, en genci 39, en yaşlısı 70 yaşında olan birinci nesil göçmenlerdir. 2 ve 6 numaralı girişimciler, Türkiye doğumlu ailelerinin kısa dönemli İran ve Kuzey Irak'ta bulunmaları nedeniyle doğum yerleri İran ve Kuzey Irak olan fakat çok küçük yaşlarda aileleri Türkiye'ye geri gelmiş ve Türkiye'de büyüyüp yetişmiş olan Türklerdir. İsveç'teki göçmenler, NUTEK (2007) ve İsveç Ekonomik ve Bölgesel Büyüme Ajansı (2008) tarafından, İsveç dışında doğmuş ve/veya ebeveynleri İsveç dışında doğmuş olan kişiler olarak tanımlamaktadır. Westin vd. (2015) kitaplarında İsveç'e göç etmiş olan Türkler örneklemini, Türkiye'de doğmuş ve/veya ebeveynleri Türkiye'de doğmuş olan kişiler şeklinde tanımlamıştır. Bu çalışmada da örneklemdeki Türkler, Türkiye'de doğmuş veya ebeveynleri Türkiye'de doğmuş olan kişilerden oluşmaktadır.

Tablo 5. Girişimler ile İlgili Temel Bilgiler

\begin{tabular}{llll}
\hline & $\begin{array}{l}\text { İlk Kuruluş } \\
\text { Yılı }\end{array}$ & $\begin{array}{l}\text { Yaklaşık Kuruluş Maliyeti } \\
\text { (İsveç Kronu, SEK) }\end{array}$ & $\begin{array}{l}\text { Çalışan } \\
\text { Sayısı }\end{array}$ \\
Girişim 1 & 1995 & 700.000 & 10 \\
Girişim 2 & 1995 & 400.000 & 4 \\
Girişim 3 & 1978 & 250.000 & 4 \\
Girişim 4 & 2003 & 800.000 & 4 \\
Girişim 5 & 2005 & 850.000 & 14 \\
Girişim 6 & 2015 & 2.000 .000 & 6 \\
Girişim 7 & 2002 & 500.000 & 4 \\
Girişim 8 & 2015 & 1.000 .000 & 5 \\
Girişim 9 & 2008 & 800.000 & 4 \\
\hline
\end{tabular}

Girişimcilerin biri üniversite (tıp fakültesi), altısı lise, biri ortaokul ve biri ilkokul mezunu erkeklerdir. Üniversite mezunu olan girişimci İsveç'e siyasi sığınmacı olarak gelmiş, diğerleri ekonomik motivasyonla göç etmiştir. Sadece 7 numaralı girişimci 3 yaşında ailesi ile göç ederek eğitim hayatının tamamını İsveç'te, diğerleri Türkiye'de geçirmiştir. Diğer sekiz girişimcinin Türkiye'den İsveç'e göç etme yaş ortalaması 26' dır. Dokuz girişimcinin üçü kendi restoranlarını açmadan önce Türkiye'de veya İsveç'te kaynakçılık, şoförlük, inşaat işçiliği ve terzilik gibi işlerde çalışmışlar, daha sonra başka restoran ve barlarda garsonluk ve aşçılık yapmışlardır. Kalan altı girişimci ise çalışma hayatının tamamını restoran ve/veya otellerin mutfaklarında geçirmiştir. 
Girişimcilerin üçü göç ettikten sonra ilk beş yıl içinde, ikisi ilk on yıl içinde, ikisi ilk onbeş yıl içinde, ve ikisi ilk yirmi beş yıl içinde restoranlarını açmışlardır. Dokuz girişimcinin tamamı kendi restoranını açmadan önce birkaç yıl başka restoranlarda çalışmışlardır.

Girişimcilerin İsveç'e göç hikayeleri birbirine oldukça benzemektedir. Dokuz girişimciden yedisinin İsveç'e ilk gidişi, orada yaşayan akrabalarını ziyaret etme şeklinde olmuştur. Bir yada iki ziyaret sonra bu yedi girişimciden altısı İsveç'te yaşayan Türk bir kadınla, biri İsveçli bir kadınla evlenmiştir. Behtoui (2015, s.57) İsveç'teki Türk göçmenlerin İsveç'te yetişen torunlarının sosyal sermayelerini incelediği çalışmasında, evli olan torunların yaklaşık \%72 sinin eşinin göçmenlerden, veya İsveç'e evlilik için gelmiş kişilerden, veya kendileri gibi Türk göçmenlerin torunlarından oluştuğunu belirtmektedir. Bu çalışmada yer alan girişimcilerin evliliklerinde de eş ile tanışma konusunda akrabaların önemli rolü olduğu, görüşülen girişimciler tarafından belirtilmiştir. Dokuz girişimciden evli olmayan ikisinden biri çok küçük yaşta ailesiyle beraber; bir diğeri ise 41 yaşında sığınmacı olarak İsveç'e göç etmiştir.

Girişimcilere işletmelerini kurma sebebi sorulduğunda, dokuz girişimcinin altısı "işsizlik" cevabını vermiştir. İsveç'e göç etmeden önce bu altı kişiden beşi Türkiye'de kaynakçılık, şoförlük, inşaat işçiliği, fabrika işçiliği, terzilik gibi az kalifiye işlerde çalışmışlardır. Tıp fakültesi mezunu olan girişimci Türkiye'de pratisyen hekimlik yapmıştır. İsveç'e göçten sonra kendi restoranlarını açmadan önce bu girişimcilerin altısı da akrabalarının veya akrabalarının restoranlarında çalışmaya başlamışlardır.

Dokuz girişimcinin üçü "girişken”, “hareketli” yapılarının ve "kendi yerini açma” hevesinin onları kendi restoranlarını açmaya yönlendirdiğinden bahsetmiştir. Bu üç girişimci de kendi restoranlarını açmadan önceki hayatları boyunca küçük yaşlardan itibaren başka restoranların mutfaklarında çalışmış olan girişimcilerdir.

Girişimcilerin kuruluş aşamasında finansmanı nasıl sağladığı konusunda Bird ve Wennberg (2016) in bulgularına çok benzer bir yapı ortaya çıkmaktadır. Dokuz girişimcinin altısı ana sermaye olarak kendi birikimlerinin yanı sıra geniş aileden aldıkları hibe ve borçları kullanmıştır. Bu hibe ve borçlar kendi birikimlerinin yaklaşık iki-üç katına kadar çıkmaktadır. Kuruluşta finansal destek sağlanan geniş aile; iki girişimci için Türkiye'deki akrabalar, dört girişimci için İsveç'teki akrabalar olmuştur. Dört girişimci kendi akrabalarından, iki girişimci Türk eşinin akrabalarından destek bulmuştur. Bu altı girişimci banka kredi olanaklarını araştırmış fakat hali hazırda gelir yaratma durumu kredi kullanmaya uygun bir işte çalışmadıklarından kredi başvuruları reddedilmiş veya kredi değerliliklerinin çok düşük olmasından dolayı banka yüksek faiz talep ettiği için kredi kullanamamıştır. Bu bulgu, Alden ve Hammarstedt (2016)' in İsveç'teki göçmen girişimcilerin finansmana erişimi ile ilgili çalışmalarındaki bulgularla paralellik göstermektedir. Onların bulguları da İsveç'teki göçmen girişimciler arasında özellikle Avrupa ülkeleri dişından göç etmiş olanların hem banka kredi başvurularının reddedilme oranının İsveçlilere ve Avrupa ülkelerinden göç etmiş olanlara kıyasla daha yüksek olduğu; hem de kullanılmak istenen borçlara ilişkin faiz oranlarının daha yüksek olduğu yönündedir. Kuruluş aşamasında aile fonlarından faydalanmayan diğer üç girişimciden biri 
sadece Türkiye'de yaptığı birikimleri kullanmış (bu girişimci İsveç'e 41 yaşında göç eden asıl mesleği doktorluk olan girişimcidir), birisi banka kredisi kullanmış (bu girişimci İsveç'e üç yaşında ailesiyle göç eden ve İsveç'te yetişen girişimcidir), biri ise kendi birikimlerinin yanı sıra kullandığı konut ve araba kredisini restoranını açmada kullanmıştır.

Kuruluş aşamasında karşılaşılan en büyük finansal sıkıntının banka kredisi bulmanın ve kullanmanın zorluğu olduğu neredeyse tüm girişimciler tarafından dile getirilmiştir. Bunun dışında özellikle ilk yıllarda toptancılardan alış-veriş etmek için uzun süreli ve yüksek fiyatlı kontrat yapmak zorunda kaldıklarından, ayrıca ilk bir ila üç yıl neredeyse hiç kar edemediklerinden ve bu sürenin uzunluğundan yakınmışlardır. Girişimciler bu süreçte ayakta kalabilmek için yine birikimlerine ve geniş ailelerinin finansal desteğine başvurduklarını belirtmiştir.

\section{Sonuç ve Değerlendirme}

Avrupa'daki Türklerin bir yönü, bu çalışmanın konusunu yakından ilgilendirmektedir. Türkler, Avrupa'da eğitim gerektirmeyen işlerde çalışanların yaklaşı \%15'ini oluşturmakta ve \%16'nın biraz üzerinde olan Makedonyalılardan sonra ikinci sırada yer almaktadır (Eklund ve Braunerhjelm, 2018: 192). Nitekim 1960'l1 yıllarda Türkiye'den İsveç'e göç edenlerin büyük çoğunluğu, İsveçlilerin o zamanlar -artık- yapmaya hevesli olmadığ 1 işleri yapmak için gitmişti. Bu yıllar aynı zamanda İsveç sanayisinin dışarıdan insan gücüne ihtiyaç duyduğu ve Nordik bölgeden, özellikle Finlandiya' dan aldığ yabancı insan gücünün yetersiz kalarak, Türkiye'den de işgücü istihdam etmeye başladığı ve Türkiye ile işgücü piyasası istihdam anlaşması yaptığı yıllardır (Larrucea, 2015).

1960'l1 yılların başında İsveç'e işçi olarak giden Türk erkek göçmenler, eşlerini ve çocuklarını yanlarına 1970' li yıllarda alabilmişler ve zaman içinde "zincir göç" denilen, aile ağları ve yerel ağlar aracılığıyla sosyal temasların göç yaratması olgusuna örnek oluşturmuşlardır. Bunu mümkün kılan, İsveç’te göçmenlerin aile bütünlüğünün sağlanmasını kolaylaştıran, o zaman geçerli olan kanunlar olmuştur. Söz konusu dönemde bu kişilerin devlet tarafından misafir işçi olarak görülmemesi, İsveç'e göçen Türkleri, hem toplumla entegrasyon hem de fırsatlar bakımından diğer Avrupa ülkelerindeki Türk göçmenlerden (olumlu yönde) farklı kılmıştır. (Larrucea, 2015, s. 28). Bu göçmenlerin çoğu Türkiye'nin kırsal kesimlerinden gelmekteydi ve dolayısıyla ortalama eğitim seviyesi düşüktü (Westin, 2015). Bununla birlikte İsveç devletinin o dönemde bu göçmen işçilere misafir muamelesi yapmaması bu kişilerin ailelerini yanlarına almalarını kolaylaştırmış ve zincir göçü başlatmıştır. 1980'li yıllarda ise ekonomik nedenli göçlerden daha çok insancıl nedenli göçler ön plana çıkmaktadır. İzleyen yıllarda diğer Avrupa ülkeleri ile birlikte İsveç devletinin de hem ekonomik hem diğer nedenlerle göç etmiş olanlara yaklaşımı zaman içinde değişime uğramıştır (Schierup, 2006; Welter, 2011).

Son on-onbeş yılda hem göçmen olmak hem de yoğun olsun olmasın, göç alan bir ülkede sosyal politika karar alıcısı olmanın her zamankinden daha zor olduğu söylenebilir. Gelişmiş ülkelere doğru göçmen akışındaki yükselme eğilimi, doğal olarak göçmenlerin bu ekonomilerde işgücü piyasasına adaptasyonu sorununu yaratmaktadır. Göçmenlerin bu sorunla başa çıkma becerisi, beşeri sermayelerinin ne kadar kalifiye olduğu ile bağlantılı olarak farklılaşmaktadır. Özellikle az kalifiye göçmenler işgücü piyasasında iş bulamadığı 
için kendi iş yerlerini açarak girişimcilik faaliyetlerinde bulunma eğilimi göstermektedir. Konuya nüfusu yaklaşık 10 Milyon olan refah devleti İsveç özelinde bakıldığında göçmenler ve göçmenlerin iş hayatına adaptasyonu konusunda politikacıların bazı somut girişimleri olsa da, İsveç'e göç eden kişiler arasında hem dil problemleri hem de kalifiye beşeri sermayenin noksanlığı istihdam konusunda göçmenler için her zaman problem oluşturmuştur. Bu araştırma kapsamında görüşülen girişimcilerin de bunu destekleyen sözleri olmuştur: “... Başka bir iş bulamayınca mecburen burayı açtım...”, “... Burada yapabileceğim tek şey pizzacilıktı...".

Göçmenlerin kendi işlerini kurmalarında göç edilen yerdeki kendilerine benzer şekilde göç etmiş olan kişilerden oluşan etnik ağların göçmenlere hem piyasalar, hem de kurumsal çevre ile ilgili bilgi sağladığı bilinmektedir. Etnik grup üyeleri birbirlerine girişimcilik faaliyetlerinde iş yerinin açılması ve faaliyetlerini sürdürmesi konularında yardım etmektedir. Özellikle etnik grubun eğitim düzeyi bakımından heterojen yapıda oluşu, iş yeri açmak için lazım olan kaynakların ve bilginin ulaşılabilirliğini kolaylaştırarak, bu yardımlaşmayı artırmaktadır (Van Tubergen, 2005). Aynı zamanda bu ağlar, finansal sermayeye erişim konusunda da ağ içindeki göçmen girişimcilere yardım etmektedir (Waldinger vd., 1990; Andersson vd., 2013). Bir finansman çözümü olarak, akrabaların desteği ve geniş ailenin fonları iş yerini kurmada girişimciler tarafından yoğun olarak kullanılmaktadır. Bu çalışma kapsamında görüşülen bir girişimcinin “... Kendi birikimim çok azdı. Eşimin ailesininkiyle birleştirince burayı açabildik. Bu süreçte önceki birikimlerimizi kullandık hep..." şeklindeki sözleri de aile fonlarının rolünü açıkça göstermektedir.

Mikro ve küçük ölçekli işletmelerin finansmana erişim ile ilgili sıkıntıları, tüm ülkeler ve tüm sektörler için farklı platformlarda tartışılmaktadır. Bu çalışma kapsamında yapılan görüşmelerde, İsveç/Göteborg özelinde restoran sahibi girişimcilerin kuruluş aşamasında karşılaştıkları en önemli finansman sorunu, banka kredisi kullanamamış olmaları olarak ortaya çıkmıştır. Kredi kullanamamalarının nedeninin, göçmen olmalarından daha çok, kredi notlarının çok düşük olması olduğu anlaşılmaktadır. Bazı girişimcilerin kredi başvurusu esnasında gelir yaratma durumu kredi kullanmaya uygun bir işte çalışmıyor olması kredi kullanamamalarına neden olmuştur. Bu çıkmazın temeldeki nedeni, girişimcilerin motivasyonlarının "işsizlik" kaynaklı "geçimini sağlamak için bir iş kurmak zorunluluğu" dur. Tabii ki bu girişimcilerin motivasyonları "kendi işini kurma", "yenilik yapma" gibi motivasyonlar olsaydı, zaten kullanılabilecek fonlar ve diğer finansman kaynakları konusunda ön araştırma ve planlama yapmış olmaları, ve banka kredilerinden faydalanmaları da daha olası olurdu. Hali hazırda kredi notu düşük olan ve geçimini sağlamak için zorunlu olarak bir iş kuran girişimciler için bu çıkmaz, bu çalışmada Göteborg bölgesindeki restoran sahipleri örneklemi için ortaya konulmuştur.

$\mathrm{Bu}$ çalışmanın örnekleminin sınırlı sayıda gözlem içermesi nedeniyle, sonuçlar dikkatli yorumlanmalıdır. Sayının sınırlı olmasının yanında, görüşülen girişimcilerin sadece Göteborg bölgesinde olması ve sadece restoran sahipleri olmasının çalışmayı bölgesel ve sektörel olarak sınırlaması nedeniyle, çalışma sonuçları genelleştirilmemelidir. Diğer Avrupa şehirlerinde çeşitli sektörlerde iş kurmuş olan göçmen girişimcilerle yapılacak benzer çalışmalar, bölgesel ve sektörel farklılıkların ortaya çıkmasına katkıda bulunacaktır. 


\section{Kaynakça}

Aaronson, D., Huck, P., \& Townsend, R. (2000). Small-business access to trade credit: Some evidence of ethnic differences (No. 2000-2). Federal Reserve Bank of Chicago.

Akresh, I. R. (2006). Occupational mobility among legal immigrants to the United States. International Migration Review, 40(4), 854-884. DOI: https://doi.org/10.1111/j.1747-7379.2006.00046.x

Aldén, L., \& Hammarstedt, M. (2016). Discrimination in the Credit Market? Access to Financial Capital among Self-employed Immigrants. Cyclops , 69 (1), 3-31. DOI: https://doi.org/10.1111/kykl.12101

Anderson, A. R., \& Miller, C. J. (2003). “Class matters": Human and social capital in the entrepreneurial process. The journal of socio-economics, 32(1), 17-36. DOI: https://doi.org/10.1016/s1053-5357(03)00009-x

Andersson, L. (2011). Occupational choice and returns to self-employment among immigrants. International Journal of Manpower, 32(8), 900-922. DOI: https://doi.org/10.1108/01437721111181660

Andersson, L., Hammarstedt, M., Hussain, S., \& Shukur, G. (2013). Ethnic origin, local labour markets and self-employment in Sweden: a multilevel approach. The annals of regional science, 50(3), 885-910. DOI: https://doi.org/10.1007/s00168-012-0525-1

Bates, T. (2011). Minority entrepreneurship. Foundations and Trends® in Entrepreneurship, 7(3-4), 151-311. DOI: https://doi.org/10.1561/0300000036

Behtoui, A. (2015). Findings of the Swedish TIES project. The Integration of Descendants of Migrants from Turkey in Stockholm, 125. DOI: https://doi.org/10.1515/9789048526956-009

Bel Habib, I. (2001). Elever med invandrarbakgrund i särskolan: specialpedagogik eller disciplinär makt. Kristianstad: Högskolan i Kristianstad. Enheten för kompetensutveckling.

Bird, M., \& Wennberg, K. (2016). Why family matters: The impact of family resources on immigrant entrepreneurs' exit from entrepreneurship. Journal of Business Venturing, 31(6), 687-704. DOI: https://doi.org/10.1016/j.jbusvent.2016.09.002

Blackburn, R., \& Ram, M. (2006). Fix or fixation? The contributions and limitations of entrepreneurship and small firms to combating social exclusion. Entrepreneurship and Regional Development, 18(1), 73-89. DOI: https://doi.org/10.1080/08985620500419566

Bourdieu, P. (2008), "The forms of capital", in Biggart, N.W. (Ed.), Readings in Economic Sociology, Blackwell Publishers, Oxford, pp. 280-292.

Braunerhjelm, P., \& Eklund, J. (2018). Migration och välfärdsstaten i Europa. Utmaningar och möjligheter. EU I En Varldsordning Under Omvandling, Europaperspektiv 2018. Santerus Academic Press Swden.

Collins, J. (2003). Cultural diversity and entrepreneurship: Policy responses to immigrant entrepreneurs in $\begin{array}{llll}\text { Australia. Entrepreneurship \& Regional Development, 15(2), 137-149. DOI: } & \end{array}$ https://doi.org/10.1080/0898562032000075168

Carlsson, M., \& Rooth, D. O. (2007). Evidence of ethnic discrimination in the Swedish labor market using experimental data. Labour Economics, 14(4), 716-729. DOI: https://doi.org/10.1016/j.labeco.2007.05.001

Constant, A. F. (2004). Immigrant versus native businesswomen: Proclivity and performance. Discussion Paper No. 1234 Institute for the Study of Labor (IZA).

Constant, A., \& Zimmermann, K. F. (2006). The making of entrepreneurs in Germany: Are native men and immigrants alike?. Small business economics, 26(3), 279-300. DOI: https://doi.org/10.1007/s11187-0053004-6

Creswell, J. W. (2013). Steps in conducting a scholarly mixed methods study.

Dalhammar, T. (2004). Voices of Entrepreneurship and Small Business - Immigrant Enterprises in Kista, Stockholm. KTH, The Royal Institute of Technology. ISSN: 1651-4114, Sweden. 
Efendic, N., Andersson, F. W., \& Wennberg, K. (2016). Growth in first-and second-generation immigrant firms in Sweden. International Small Business Journal, 34(8), 1028-1052. DOI: https://doi.org/10.1177/0266242615612533

Eimermann, M., \& Karlsson, S. (2018). Globalising Swedish Countrysides? A Relational Approach to Rural Immigrant Restaurateurs with Refugee Backgrounds. Norwegian Journal of Geography, 72(2), 82-96. DOI: https://doi.org/10.1080/00291951.2018.1450781

Evansluong, Q.V.D. (2016). Opportunity Creation as a Mixed Embedding Process: A Study of Immigrant Entrepreneurs in Sweden. Doctoral Thesis, Jönköping University, No: 110-2016, Sweden.

Fairlie, R. W., \& Krashinsky, H. A. (2012). Liquidity constraints, household wealth, and entrepreneurship revisited. Review of Income and Wealth, 58(2), 279-306. DOI: https://doi.org/10.1111/j.14754991.2011.00491.x

Fairlie, R. W., \& Lofstrom, M. (2015). Immigration and entrepreneurship. In Handbook of the economics of international migration (Vol. 1, pp. 877-911). North-Holland. DOI: https://doi.org/10.1016/B978-0-44453768-3.00017-5

Feldman, J. M. (2006). The limits and possibilities of ethnic entrepreneurship: the case of ICT firms in Sweden. International Journal on Multicultural Societies, 8(1), 84-101.

Hazlina Ahmad, N., Ramayah, T., Wilson, C., \& Kummerow, L. (2010). Is entrepreneurial competency and business success relationship contingent upon business environment? A study of Malaysian SMEs. International Journal of Entrepreneurial Behavior \& Research, 16(3), 182-203. DOI: https://doi.org/10.1108/13552551011042780

Hedberg, C. (2009). Intersections of Immigrant Status and Gender in the Swedish Entrepreneural Landscape. Working Paper 2009:8. The Stockholm University Linnaeus Center for Integration Studies (SULCIS). ISSN: 1654-1189, Sweden.

Hjerm, M. (2004). Immigrant entrepreneurship in the Swedish welfare state. Sociology, 38(4), 739-756. DOI: https://doi.org/10.1177/0038038504045862

Karmel, S., \& Bryon, J. (2002). A Comparison of Small and Medium Sized Enterprises in Europe and in the USA. Routledge. DOI: https://doi.org/10.4324/9780203166031

Kothari, C. R. (2004). Research methodology: Methods and techniques. New Age International.

Kushnirovich, N., \& Heilbrunn, S. (2008). Financial funding of immigrant businesses. Journal of Developmental Entrepreneurship, 13(02), 167-184. DOI: https://doi.org/10.1142/s1084946708000910

Levent, T.B. (2002). The demographic transition and urban development in Turkey. Chapters.

Levent, T.B., \& Nijkamp, P. (2009). Characteristics of migrant entrepreneurship in Europe. Entrepreneurship and Regional Development, 21(4), 375-397. DOI: https://doi.org/10.1080/08985620903020060

Lofstrom, M., \& Wang, C. (2006). Hispanic self-employment: A dynamic analysis of business ownership. DOI: https://doi.org/10.2139/ssrn.900377

Mac an Bhaird, C. (2010). Resourcing small and medium sized enterprises: A financial growth life cycle approach. Springer Science \& Business Media. DOI: https://doi.org/10.1007/978-3-7908-2399-8

Marger, M. N. (2001). Social and human capital in immigrant adaptation: The case of Canadian business immigrants. The Journal of Socio-Economics, 30(2), 169-170. DOI: https://doi.org/10.1016/s10535357(00)00099-8

Masurel, E., Nijkamp, P., Tastan, M., \& Vindigni, G. (2001). Motivations ad performance conditions for ethnic entreneurship. Tinbergen Institute Discussion Paper TI 2001-048/3, Amsterdam.

NUTEK (2007) Invandrares företagande. En studie av utlandsfödda företagare i Sverige, Stockholm: Danagårds Grafiska. 
Ostrovsky, Y., Picot, G., \& Leung, D. (2019). The financing of immigrant-owned firms in Canada. Small Business Economics, 52(1), 303-317. DOI: https://doi.org/10.1007/s11187-018-0020-x

Patton, M. Q. (2005). Qualitative research. Encyclopedia of statistics in behavioral science. DOI: https://doi.org/10.1002/0470013192.bsa514

Rauhut, D., \& Rauhut Kompaniets, O. (2018). The impact of immigrant entrepreneurship on regional development in Western Sweden. Romanian Journal of Regional Science, 12(1), 18-42.

Sanders, J. M., \& Nee, V. (1996). Immigrant self-employment: The family as social capital and the value of human capital. American sociological review, 231-249. DOI: https://doi.org/10.2307/2096333

Schierup, C. U. (2006). Den sociala exkluderingen i Sverige. Migration, arbetsmarknad och välfärdsstat i förändring. I P. de los Reyes (Ed.), Arbetslivets (o) synliga murar.(Rapport av Utredningen om makt, integration och strukturell diskriminering). SOU, 59.

Schröder, L. (2015). 7 The labour market. The Integration of Descendants of Migrants from Turkey in stockholm, 20(24), 103. DOI: https://doi.org/10.1515/9789048526956-008

Sequeira, J. M., \& Rasheed, A. A. (2006). Start-up and growth of immigrant small businesses: The impact of social and human capital. Journal of Developmental Entrepreneurship, 11(04), 357-375. DOI: https://doi.org/10.1142/s1084946706000490

Stark, O., \& Wang, Y. (2002). Inducing human capital formation: migration as a substitute for subsidies. Journal of Public Economics, 86(1), 29-46. DOI: https://doi.org/10.1016/s0047-2727(01)00104-9

Statistics Sweden https://www.scb.se/

Sundararajan, M., \& Sundararajan, B. (2015). Immigrant capital and entrepreneurial opportunities. Entrepreneurial Business and Economics Review, 3(3), 29-50. DOI: https://doi.org/10.15678/eber.2015.030303

Sweden Agency for Economic and Regional Growth (2008). Mångfald I näringslivet. Företagens villkor och verklighet, Stockholm: DanagårdLiTHO AB.

Tseng, Y. F. (1997). Immigration consulting firms in Taiwanese business immigration. Asian and Pacific Migration Journal, 6(3-4), 275-294. DOI: https://doi.org/10.1177/011719689700600302

Valdez, Z. (2003). Beyond ethnic entrepreneurship: Ethnicity and the economy in enterprise.

Van Tubergen, F. (2005). Self-employment of immigrants: A cross-national study of 17 western societies. Social forces, 84(2), 709-732. DOI: https://doi.org/10.1353/sof.2006.0039

Vera Larrucea, C. (2015). Historical and demographical considerations. The integration of descendants of migrants from Turkey in Stockholm, 25-42. DOI: https://doi.org/10.1515/9789048526956-003

Waldinger, R. D., Aldrich, H., \& Ward, R. (1990). Ethnic entrepreneurs: Immigrant business in industrial societies (Vol. 1). Sage Publications, Inc.

Welter, F. (2011). Contextualizing entrepreneurship-conceptual challenges and ways forward. Entrepreneurship theory and Practice, 35(1), 165-184. DOI: https://doi.org/10.1111/j.15406520.2010.00427.x

Westin, C. (Ed.). (2015). The integration of descendants of migrants from Turkey in Stockholm: The TIES study in Sweden. Amsterdam University Press. DOI: https://doi.org/10.5117/9789089648419

Yazdanfar, D., Abbasian, S., \& Brouder, P. (2015). Business advice strategies of immigrant entrepreneurs in Sweden. Baltic Journal of Management, 10(1), 98-118. DOI: https://doi.org/10.1108/BJM-01-2014-0018

Zhou, M. (2004). Revisiting ethnic entrepreneurship: Convergencies, controversies, and conceptual advancements 1. International migration review, 38(3), 1040-1074. DOI: https://doi.org/10.1111/j.17477379.2004.tb00228.x

https://www.citypopulation.de/en/sweden/metrogoteborg/ 